\title{
Influence of pH and Ionic Strength on Treatment of Radioactive Boric Acid Wastes by Forward Osmosis Membrane
}

\section{정삼투막에 의한 붕산함유 방사성 폐액 처리를 위한 $\mathrm{pH}$ 및 이온강도 영향}

Hye-Min Choi, Doo-Seong Hwang*, Kune-Woo Lee and Jei-Kwon Moon

Korea Atomic Energy Research Institute, 111, Daedeok-daero 989, Yuseong, Daejeon, Korea

최혜민, 황두성*, 이근우, 문제권

한국원자력연구원, 대전광역시 유성구 대덕대로 989번길 111

(Received April 30, 2013 / Revised June 7, 2013 / Approved August 23, 2013)

In general, boron recovery of $40-90 \%$ could be achieved by Reverse Osmosis $(\mathrm{RO})$ membranes in neutral $\mathrm{pH}$ condition. As an emerging technology, Forward Osmosis (FO) membrane has attracted growing interest in wastewater treatment and desalination. The objective of this study is to evaluate the possibility of the boron removal in radioactive liquid waste by FO. In this study, the performance of FO was investigated to remove boron in the simulated liquid waste as the factors such as $\mathrm{pH}$, osmotic pressure, ionic strength of solution, etc. The $\mathrm{pH}$ of feed solution is a major operating parameter which strongly influences to the permeation of boron and more than $80 \%$ of boron content can be separated when conducted at $\mathrm{pH}$ values less than 7 . The water flux is not influenced but the boron flux and permeation rate tends to decrease in the low salt concentration of $1,000 \mathrm{mg} / \mathrm{L}$. The boron flux increases linearly, but the permeation ratio of reducing boron is nearly constant even with changes in the draw solution concentration.

Key words: Forward osmosis, Boron removal, Ionic strength, $\mathrm{pH}$

일반적으로 역삼투압 공정에 의해 중성 $\mathrm{pH}$ 조건에서 $40 \sim 90 \%$ 의 붕소를 회수할 수 있다. 정삼투공정은 새로운 선진 기술로 폐수처리 및 담수화 분야에서 관심이 높아지고 있다. 본 연구의 목적은 정삼투공정으로 방사성 액체 폐기물의 붕소제거 가 능성을 고찰하고자 하는데 있다. 액체폐기물에서의 붕소 제거를 위한 정삼투공정의 성능을 평가하기 위해 $\mathrm{pH}$, 삼투압, 용 액의 이온강도 등을 고려하였다. 폐액의 붕산분리능을 좌우하는 주 조업변수인 $\mathrm{pH}$ 조건은 $\mathrm{pH} 7$ 이하에서 $80 \%$ 이상의 붕소 분리를 달성할 수 있었다. 약 $1,000 \mathrm{mg} / \mathrm{L}$ 정도의 염농도에서는 막의 물의 플럭스는 거의 영향이 없었으나 붕소 투과율은 약 간 감소하는 경향을 나타내었다. 공급액 내 붕소 농도 증가에 따라 붕소플럭스는 선형적으로 증가하였으며, 붕소의 투과율 은 약 $80 \%$ 정도로 일정하였다.

중심단어 : 정삼투, 붕소 제거, 이온강도, $\mathrm{pH}$

*Corresponding Author. E-mail: dshwang@kaeri.re.kr, Tel: +82.42.868.8586 
Hye-Min Choi. et al : Influence of $\mathrm{pH}$ and Ionic Strength on Treatment of Radioactive Boric Acid Wastes by Forward Osmosis Membrane

\section{1. 서 론}

대부분의 경수로형 원자력발전소에서는 바닥 및 기기 배수 폐액, 화학제 폐액, 기타 폐기물 등이 발생하며, 이러 한 폐기물은 폐기물 저장탱크에 수집 후 증발 농축기에 의 해서 처리되고 있다. 폐액내의 붕산은 증발기의 처리효율 을 저하시키며 농축도를 제한하는 요인이 되고 있다. 경수 로형 원자로는 보통 1 차 계통에 주입한 붕산의 양으로 원 자로 출력을 조절하고, 붕산은 중성자를 흡수하여 중성자 에 의한 연쇄반응을 줄여서 원자로를 제어한다. 경수로의 1 차 냉각수 계통의 폐액은 냉각수내 붕산농도 조절과 누 수에 의해 발생되며 $0.3 \sim 0.8 \mathrm{wt} \%$ 의 붕산이 함유되어 있다 [1]. 붕산함유 액체폐기물은 증발기를 이용하여 농축처리하 고, 증발기의 운전조건은 폐액 내에 있는 붕산의 물리· 화 학적 특성에 의해 좌우된다. 즉, 붕산 폐액 내 붕산농도가 폐액 발생기의 농축 한계 물질로 작용하여 고체폐기물의 양을 증대 시키는 요인이 된다. 따라서 액체폐기물에서 붕 산의 분리를 통해 고체 폐기물 발생량을 줄일 수 있다. 붕 산은 일반적으로 붕사(Borax)로 부터 얻어진다. 이는 물 에서 비교적 잘 용해되며, 용해도는 온도증가에 따라 급격 히 증가한다. 붕산은 약산으로 존재하며 약간의 휘발성 물 질이다[2,3]. 붕산은 Fig. 1 에 나타낸 바와 같이 용액 내에서 $\mathrm{B}(\mathrm{OH})_{3}, \mathrm{~B}(\mathrm{OH})_{4}^{-}, \mathrm{B}_{2}(\mathrm{OH})_{7}^{-}$, 그리고 $\mathrm{B}_{3}(\mathrm{OH})_{10}{ }^{-}$와 같은 여 러 가지 붕소화합물로 존재한다고 보고되고 있다[4]. 붕소 화합물은 $\mathrm{pH}$ 에 따라 다양하게 존재하며, $\mathrm{pH}$ 7이하에서는 대부분이 분자상태의 붕산 $\left(\mathrm{B}(\mathrm{OH})_{3}\right)$ 으로 존재하고, $\mathrm{pH} 10$ 이상에서는 $\mathrm{B}(\mathrm{OH})_{4}$ 로 대부분 존재한다. $\mathrm{pH} 7$ 에서 $\mathrm{pH} 10$ 사이에서는 $\mathrm{B}(\mathrm{OH})_{3}$ 와 $\mathrm{B}(\mathrm{OH})_{4}$ 가 대부분 존재하지만 약 간의 $\mathrm{B}_{2}(\mathrm{OH})_{7}^{-}$와 $\mathrm{B}_{3}(\mathrm{OH})_{10}{ }^{-}$로도 미량 존재하는 것으로 나 타내고 있다.

일반적으로 중성 $\mathrm{pH}$ 조건에서 역삼투압 분리공정에 의해 40 90\%의 붕소를 분리할 수 있다[5]. 정삼투압 분리 공정은 이러한 역삼투압 분리공정과 달리 높은 압력을 가 하지 않고 삼투압을 이용하므로 에너지 효율을 $50 \%$ 까지 증대시킬 수 있어 담수, 정수, 폐수 처리를 위한 차세대 분 리공정으로 기대되고 있다. 정삼투압 분리공정은 상압 운 전에 의한 에너지 소모 및 막오염이 낮고, 염 제거 효율 또 한 우수한 장점이 있다[6].

본 연구에서는 정삼투압 분리막을 이용한 방사성 폐액 내 붕산의 선택적 분리를 위해 유도용액의 종류, 삼투압 변 화 및 공급용액의 $\mathrm{pH}$, 이온강도, 붕산농도 등에 따른 붕산 의 분리능 등 정삼투 분리막의 성능을 고찰하고자 하였다.

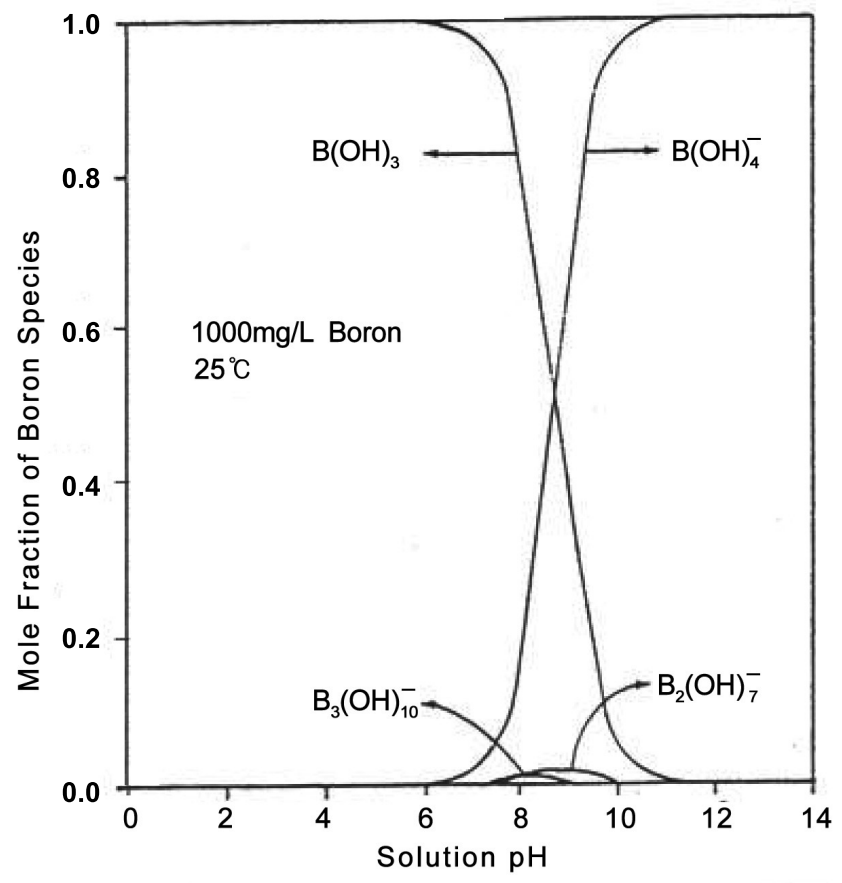

Fig. 1. Distribution of the hydrolyzed species in aqueous solution of boric acid[1].

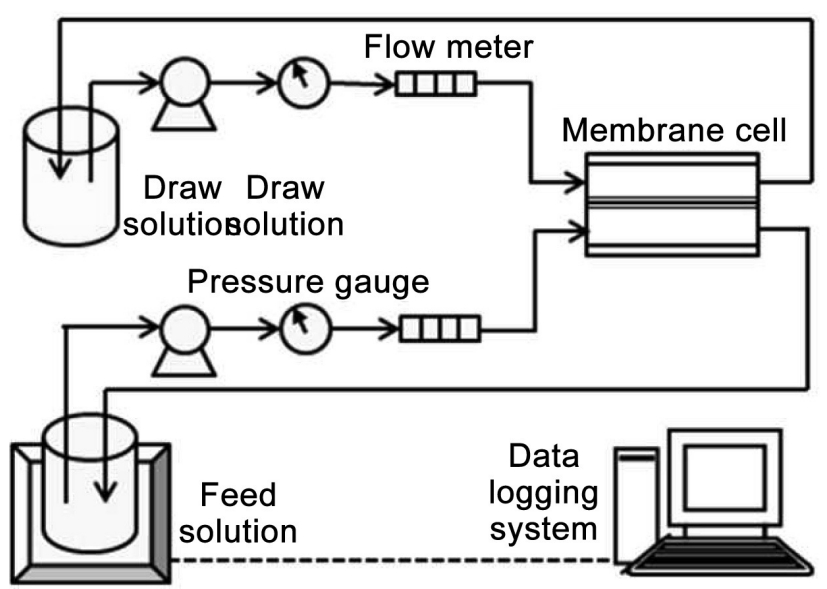

Fig. 2. Schematic diagram of the forward osmosis system.

\section{2. 실험장치 및 방법}

\section{1 정삼투압 장치 (Forward Osmosis Sys- tem)}

정삼투 공정을 간략하게 도식화하여 Fig. 2에 나타내 었다. 장치의 구성은 유량 조절계와 압력펌프가 장착되어 
있으며, 공급용액과 유도용액이 분리막 묘듈을 경계로 순 환할 수 있도록 구성되어 있다. 실험에 사용된 막의 면적 은 $50 \times 100 \mathrm{~mm}$ 이며 용액 접촉면적을 $2 \times 50 \times 100 \mathrm{~mm}$ 의 크 기로 분리막 모듈을 제작하였다. 사용된 막은 HTI (Hydrowell Filter System)사의 CTA-NW이다.

\section{2 분리막 특성 및 유도용액 선정}

정삼투막은 부직포에 셀루로오즈 트리아세테이트를 주입하여 제조한 분리막으로서 전형적인 박막 복합막이 다. Fig. 3은 정삼투막의 막활성층과 막지지층 면과 막의 단면을 나타낸 것이다.

유도용액에 따른 이론적 삼투압의 크기는 $\mathrm{MgCl}_{2}$ $>\mathrm{CaCl}_{2}>>\mathrm{NaCl}>\mathrm{KCl}>$ Sucrose $>\mathrm{MgSO}_{4}>\mathrm{KNO}_{3}>$ $\mathrm{NH}_{4} \mathrm{HCO}_{3}$ 의 순으로 알려져 있다[6]. 따라서 본 연구에서 는 유도용액의 선정에 있어서 삼투압이 가장 큰 $\mathrm{MgCl}_{2}$ 와 정삼투압 연구에 많이 사용되는 $\mathrm{NaCl}$ 두 종류에 대하여 물의 플럭스를 조사 하였다. Fig. 4 는 삼투압 변화에 따른 $\mathrm{MgCl}_{2}$ 과 $\mathrm{NaCl}$ 의 물의 플럭스 변화를 나타낸 것이다. 삼투 압을 10 100 atm까지 변화를 주었을 때 삼투압이 증가할 수록 $\mathrm{MgCl}_{2}$ 과 $\mathrm{NaCl}$ 모두 플럭스가 증가하는 경향을 보였
다. 삼투압은 $\mathrm{NaCl}$ 보다 $\mathrm{MgCl}_{2}$ 가 크지만 동일한 삼투압에 서의 플럭스는 $\mathrm{NaCl}$ 이 큰 것으로 나타났다. 이는 막지지 층에서의 내부농도분극이 원인인 것으로 생각된다. 일반 적으로 유도용액의 점도가 크면 클수록, 확산계수가 작으 면 작을수록 막지지층에서의 내부농도분극의 정도가 증가 하는 것으로 알려져 있다. 따라서 막지지층에서의 내부농 도 증가에 따라 유도용액에 따라 동일한 삼투압에서 물의 플럭스 차이가 나는 것으로 판단된다[7].

\section{3 실험 재료 및 방법}

용액 제조에 사용된 시약으로는 Sodium chloride $(\mathrm{NaCl}$, $99.5 \%)$, Magnesium chloride hexahydrate $\left(\mathrm{MgCl}_{2} \cdot 6 \mathrm{H}_{2} \mathrm{O}\right.$ $98.0 \%)$, Boric $\operatorname{acid}\left(\mathrm{H}_{3} \mathrm{BO}_{3}, 99.5 \%\right)$ 이다. 용액의 $\mathrm{pH}$ 측정 을 위해서 Orion 3 Star Plus pH meter를 사용하였다. 또 한 붕소 분석을 위한 분석 장치로 유도결합플라즈마방출 분광기(Inductively Coupled Plasma Atomic Emission Spectrometry, OPTIMA $7300 \mathrm{DV}$ )를 사용하였다. 사용된 막의 SEM 이미지 분석을 위해 주사전자현미경(Scanning Electron microscope, SEM 5200)을 사용하였다.

공급용액의 유량은 $1.5 \mathrm{~L} / \mathrm{min}$, 유도용액의 유량은 $1 \mathrm{~L} /$

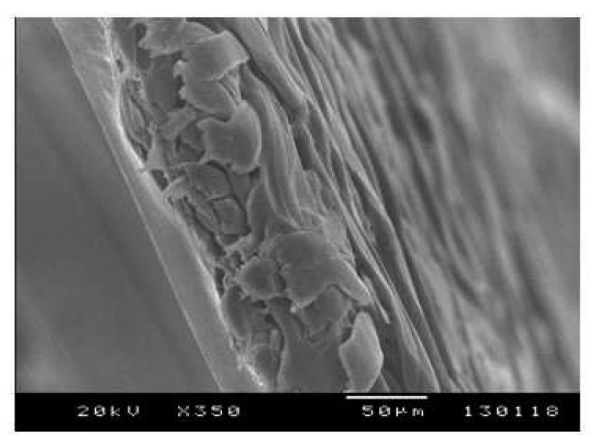

(a)

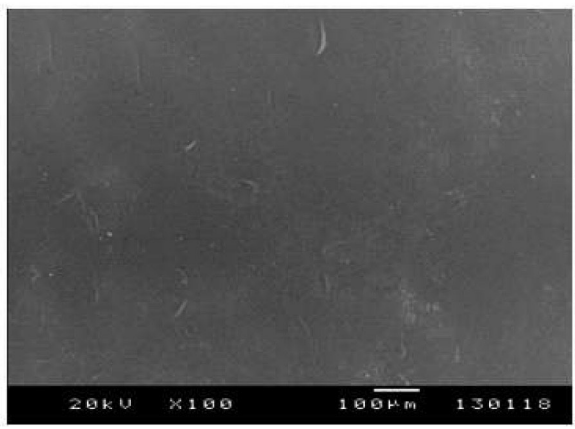

(b)

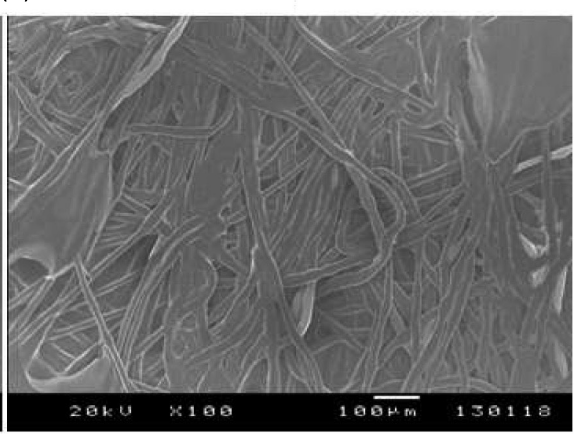

(c)

Fig. 3. SEM images of the forward osmosis membrane (a) cross section (b) front active layer surace (c) back support layer surface. 
Hye-Min Choi. et al : Influence of $\mathrm{pH}$ and Ionic Strength on Treatment of Radioactive Boric Acid Wastes by Forward Osmosis Membrane

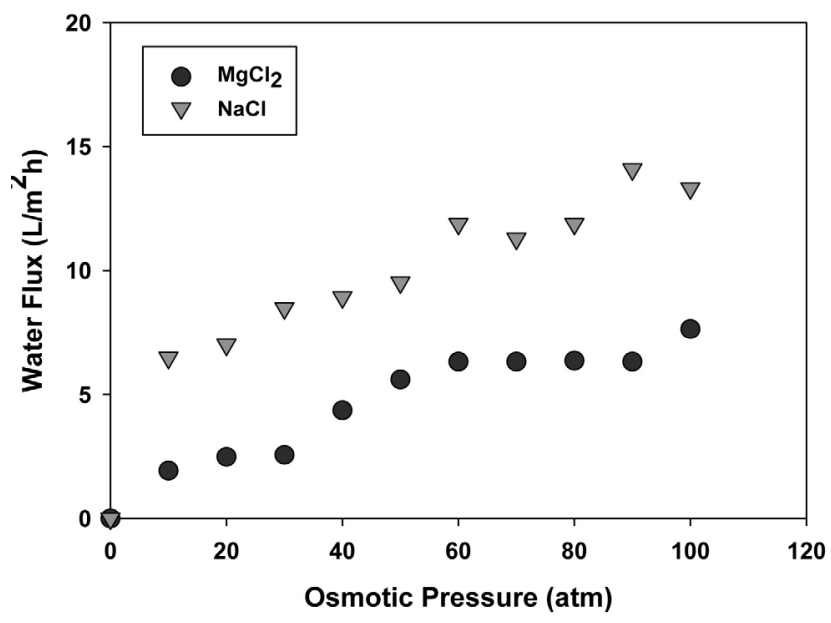

Fig. 4. Water flux as a osmotic pressure of the draw solution $\left(\mathrm{MgCl}_{2}\right.$ and $\mathrm{NaCl})$.

$\min$ 으로 일정하게 조절하였으며, 공급용액의 용량은 약 $250 \mathrm{~mL}$ 가 사용되었다. 공급용액에는 $300 \mathrm{mg} / \mathrm{L}$ 의 붕소를 사용하였으며, 유도용액로 $\mathrm{NaCl}$ 을 사용하였고, 유도용액 의 이론적 삼투압은 $\mathrm{NaCl}$ 의 농도를 조절하여 얻었다. $\mathrm{pH}$ 의 변화에 따른 붕산의 분리능을 조사하기 위하여 공급 용액의 $\mathrm{pH}$ 를 $0.5 \mathrm{M} \mathrm{NaOH}$ 용액을 사용하여 조절하였다. 이온강도의 영향을 조사하기 위하여 공급용액 내 $\mathrm{KCl}$ 을 $0-1,000 \mathrm{mg} / \mathrm{L}$ 의 농도로 변화시키며 조사하였다. 또한 붕 산농도의 영향을 조사하기 위하여 공급용액 내 붕소 농도 를 100-1,500 mg/L의 범위로 변화시켜 조사하였다. 공급 용액은 막의 활성층면, 유도용액은 막의 지지층면으로 하 고 각 용액을 같은 방향으로 흐르도록 장착하여 30 분간 용 액을 순환시켜 공급용액의 무게 감량을 전자저울로 측정 하여 물 및 붕소 플럭스를 도출하였다.

\section{3. 결과 및 논의}

\section{$3.1 \mathrm{pH}$ 변화에 따른 붕산 분리능}

Fig. 5는 공급용액의 $\mathrm{pH}$ 변화에 따른 물과 붕소의 플 럭스 변화를 나타낸 것이다. 공급용액 내 붕소 농도는 300 $\mathrm{mg} / \mathrm{L}$, 유도용액의 삼투압은 $40,80 \mathrm{~atm}$ 인 조건에서 실험 을 수행하였다. 물의 플럭스는 공급용액의 $\mathrm{pH}$ 변화에 관 계없이 일정하였으며, 붕소 플럭스는 $\mathrm{pH} 7$ 부터 감소하는 경향을 보여주고 있다. 이는 앞에서 언급한 바와 같이 공 급용액 내 $\mathrm{pH}$ 변화에 따라 존재하는 붕소화합물 화학종 과 관계가 있는 것으로 생각된다. $\mathrm{pH}$ 7이하에서는 붕소

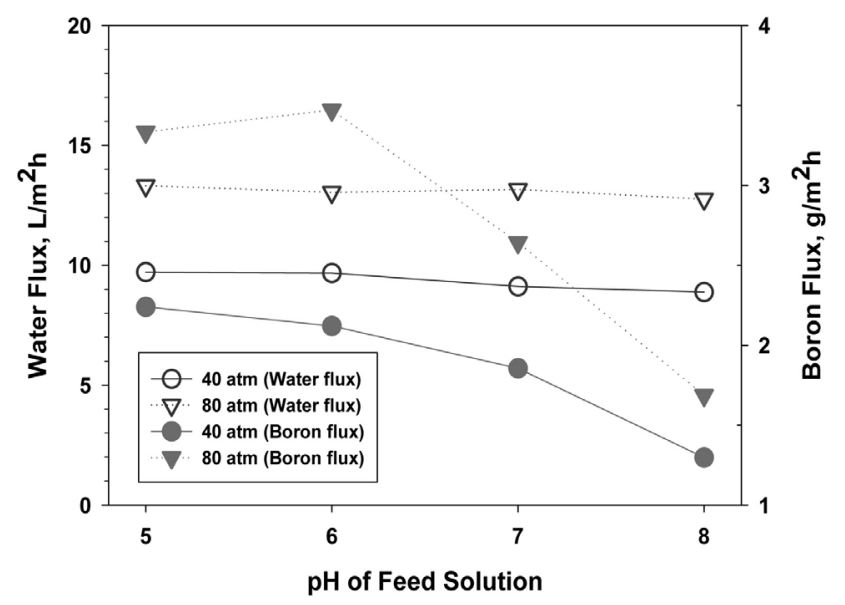

Fig. 5. Water and boron flux as a $\mathrm{pH}$ of the feed solution.

는 붕산의 형태로 존재하고 그 이상에서는 붕소는 이온 성 붕소화합물로 존재한다. 붕산은 분리막을 통과하고 이 온성 붕소화합물은 통과하지 못함을 알 수 있다. 또한 삼 투압의 증가에 따라 물 및 붕소 플럭스는 증가하는 것으 로 나타났으며, 이는 추진력의 증가에 따른 당연한 결과 임을 알 수 있다.

Fig. 6은 pH 변화에 따른 붕소의 투과율을 나타낸 것 이다. 반투막 내 붕소의 투과율은 다음과 같이 나타낼 수 있다.

$$
\begin{aligned}
\text { 붕소 투과율 } & =\mathrm{C}_{\mathrm{d}, \mathrm{B}} / \mathrm{C}_{\mathrm{f}, \mathrm{B}}\left(\mathrm{C}_{\mathrm{d}, \mathrm{B}}=\mathrm{J}_{\mathrm{B}} / \mathrm{J}_{\mathrm{W}}\right) \\
& =\mathrm{J}_{\mathrm{B}} /\left(\mathrm{J}_{\mathrm{W}^{*} \mathrm{C}_{\mathrm{f}, \mathrm{B}}}\right)
\end{aligned}
$$

여기서 $\mathrm{C}_{\mathrm{f}, \mathrm{B}}$ 와 $\mathrm{C}_{\mathrm{d}, \mathrm{B}}$ 는 각각 공급용액 및 유도용액에서 의 붕소 농도이고 $\mathrm{J}_{\mathrm{B}}$ 와 $\mathrm{J}_{\mathrm{W}}$ 는 각각 붕소와 물의 플럭스이다. 삼투압이 $80 \mathrm{~atm}$ 인 경우 붕소의 투과율은 $\mathrm{pH} 6$ 이하에서 약 $80 \%$ 이상 나타났으며, $\mathrm{pH}$ 증가에 따라 감소하는 것으 로 나타났다. 그러나 Fig. 5는 삼투압변화에 따라 물 및 붕 소의 플럭스 차이가 큰 반면 투과율은 크게 차이가 나지 않음을 볼 수 있다. 붕소의 투과율은 위 정의에 나타낸 바 와 같이 붕소와 물 플럭스의 상관관계로 결정되며, 이들 은 삼투압의 변화에 상관없이 일정함을 알 수 있다. 즉, 물 과 붕소의 플럭스는 삼투압이 증가함에 따라 비례하여 증 가하지만 붕소의 투과율에는 영향을 미치지 않음을 확인 할 수 있다. 따라서 효율적인 붕산 분리를 위해서는 $\mathrm{pH} 7$ 이하 및 높은 삼투압의 조건에서 조업해야함을 알 수 있으 나, 최적의 삼투압 조건은 공급용액의 감용율 및 유도용액 의 재사용 조건 등 효율적인 공정 조건을 고려하여 결정 
Hye-Min Choi. et al : Influence of $\mathrm{pH}$ and Ionic Strength on Treatment of Radioactive Boric Acid Wastes by Forward Osmosis Membrane

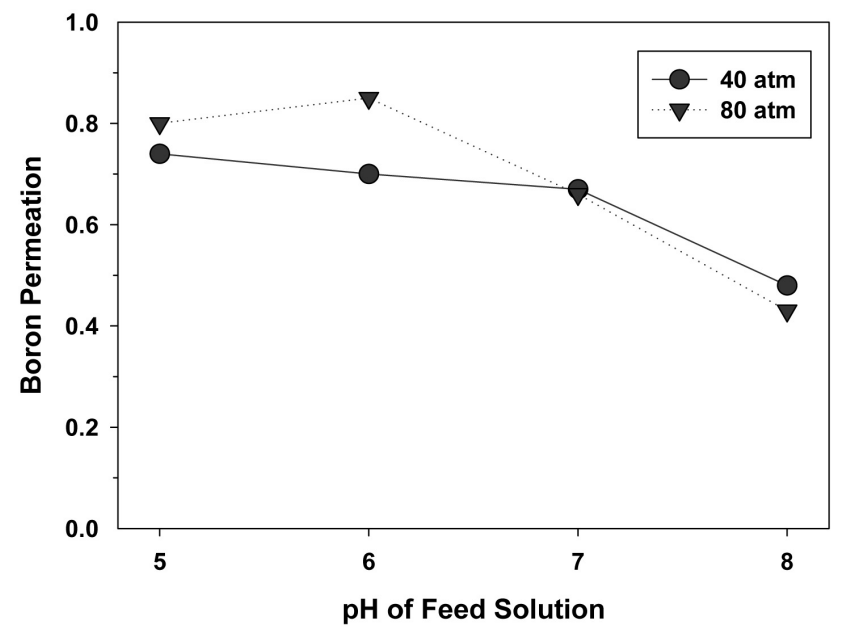

Fig. 6. Boron permeation as a $\mathrm{pH}$ of the feed solution.

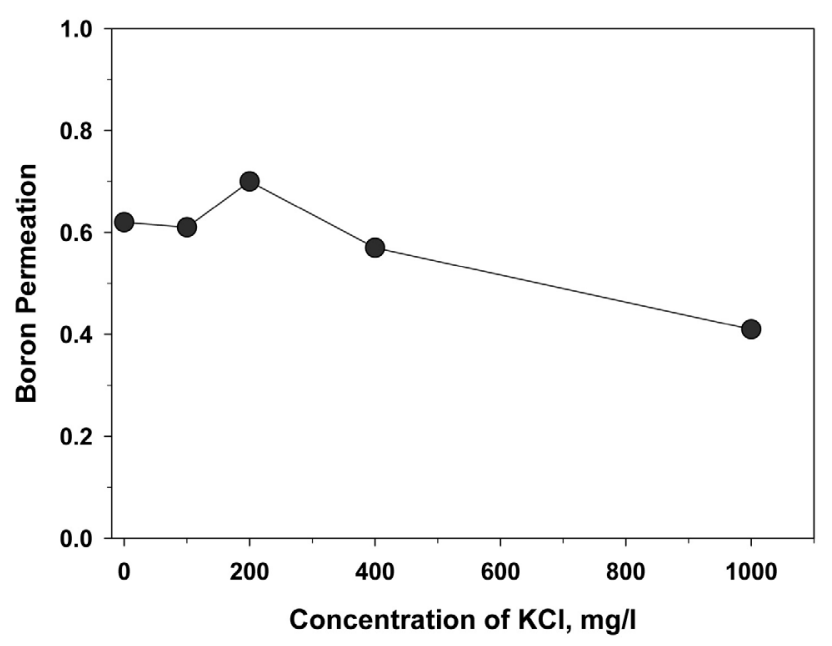

Fig. 8. Boron permeation rate as a concentration of $\mathrm{KCl}$.

되어야 한다.

\section{2 염 농도에 따른 붕산 분리능}

Fig. 7은 공급용액의 pH 6 및 붕소농도가 $300 \mathrm{mg} / \mathrm{L}$ 와 유도용액의 삼투압이 $80 \mathrm{~atm}$ 인 조건에서 염 농도 증가에 따른 물 및 붕산의 플럭스 변화를 나타낸 것이다. 염은 $\mathrm{KCl}$ 을 사용하였고 공급용액 내 염 농도는 0 1000 mg/L의 범 위에서 조사하였다. 물의 플럭스는 염농도 증가에 따라 일 정한 값을 나타내었다. 일반적으로 염농도 증가에 따라 물 의 플럭스는 감소하는 것으로 알려져 있다[8]. 따라서 물 투과율이 염농도 증가에 영향을 받지 않은 것은 염농도가 $1,000 \mathrm{mg} / \mathrm{L}$ 정도로 낮은데 기인한 것으로 판단된다. 그

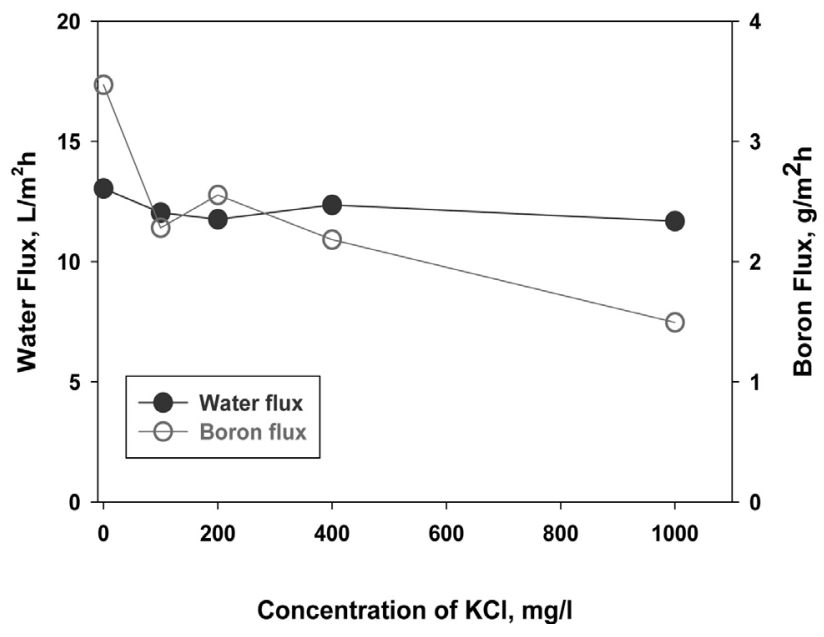

Fig. 7. Water and boron flux as a concentration of $\mathrm{KCl}$.

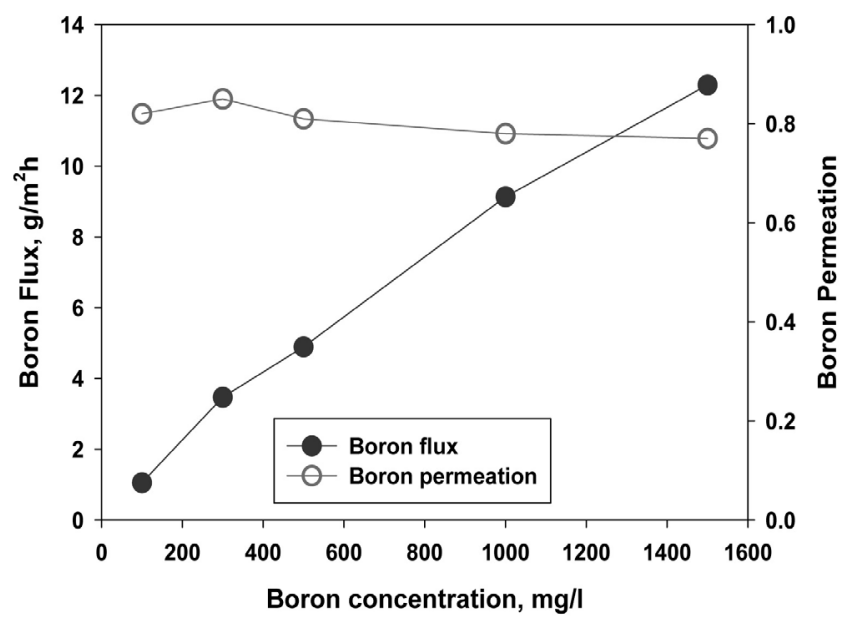

Fig. 9. Boron flux and permeation rate as a boron concentration.

러나 붕소 플럭스는 염 농도 증가에 따라 감소하는 경향 을 보여주고 있다. 따라서 물과 달리 붕소는 염 농도 증가 에 따라 어느 정도 투과율에 영향을 받는 것으로 판단된다. Fig. 8은 염농도 증가에 따른 붕소의 투과율을 나타낸 것으 로서 붕소플럭스와 마찬가지로 감소하는 경향을 나타내었 다. 따라서 폐액 처리 시 폐액 내 함유된 염의 농도는 폐액 의 감용율 및 붕소 분리에 영향을 미치는 인자로 작용하므 로 공정 조건의 주요 인자로 고려해야할 것이다.

\section{3 붕소 농도 증가에 따른 붕산 분리능}

Fig.9는 공급용액의 pH 6 및 유도용액의 삼투압이 80 atm인 조건에서 공급용액 내 붕소농도 증가에 따른 붕소 
Hye-Min Choi. et al : Influence of $\mathrm{pH}$ and Ionic Strength on Treatment of Radioactive Boric Acid Wastes by Forward Osmosis Membrane

의 플럭스 및 투과율 변화를 나타낸 것이다. 여기서 물의 플럭스는 붕소 농도의 증가에 관계없이 일정하여 그림에 나타내지 않았다. 붕소의 플럭스는 붕소 농도 증가에 따라 선형적으로 증가함을 보여주고 있으며, 붕소의 투과율은 약 $80 \%$ 정도로 붕소 농도 증가에 관계없이 일정함을 보여 주고 있다. 분리막을 이용한 음용수 내 붕산제거와 관련한 연구결과[9]의 경우 붕소농도 약 $50 \mathrm{mg} / \mathrm{L}$ 이하에서 붕소농 도 증가에 따라 붕소플럭스가 선형적 증가하는 것으로 보 고된 바 있으나, 본 실험결과와 같이 $1,500 \mathrm{mg} / \mathrm{L}$ 의 농도에 서도 선형적으로 붕소 플럭스가 증가하는 결과를 나타내 었다. 이는 폐액 내 붕산을 분리하면서 폐액의 감용율을 높 임으로서 폐액을 처리 효율을 높일 수 있는 기초 자료로 사 용될 수 있을 것으로 판단된다.

\section{4. 결 론}

정삼투공정을 이용하여 붕산이 함유된 폐액의 붕산 분 리능을 평가하기 위해 $\mathrm{pH}$, 삼투압, 용액의 이온강도 등을 고려하였다. 본 연구에서 유도용액은 동일한 삼투압에서 물의 플럭스가 큰 $\mathrm{NaCl}$ 을 사용하였다. 물의 플럭스는 공급 용액의 $\mathrm{pH}$ 변화에 관계없이 일정하였으며, 붕소 플럭스는 $\mathrm{pH} 7$ 부터 감소하였으며, $\mathrm{pH} 7$ 이하에서 붕소의 투과율은 약 $80 \%$ 이상 나타났다. 약 $1,000 \mathrm{mg} / \mathrm{L}$ 정도의 염농도에서 는 막의 물 플럭스는 거의 영향이 없었으나 붕소 투과율은 약간 감소하는 경향을 나타내었다. 공급액 내 붕소 농도 증 가에 따라 붕소플럭스는 선형적으로 증가하였으며, 붕소 의 투과율은 약 $80 \%$ 정도로 일정하였다. 따라서 폐액 처리 시 폐액 내 함유된 염과 붕소의 농도는 폐액의 감용율 및 붕소 분리에 상호 영향을 미치는 주요인자로 작용하므로 공정 조건 선정 시 주요 기초자료로 사용될 수 있을 것으로 판단된다. 향후 정삼투 분리막의 특성에 따른 붕소 분리 능 및 유도용액의 회수 등의 연구를 수행함으로써 실제 붕 산 함유 방사성폐액 내 붕산의 선택적 분리 및 회수 공정 을 개발할 수 있을 것으로 예측된다.

\section{감사의 글}

이 논문은 2012년도 정부(미래창조과학부)의 재원으 로 한국연구재단의 지원을 받아 수행된 연구입니다. (원 자력연구개발사업, NRF-2012M2A8A1030164)

\section{REFERENCES}

[1] K.W. Lee, S. H. Cho, H. H. Park and J. H. Kim, "Treatment of Radioactive Boric Acid Wastes by Reverse Osmosis Membrane", J. Kor. Soc. Environ. Eng., 16(3), 405-413 (1994).

[2] F.A. Cottin and G. Wilinson, "Advanced Inorganic Chemistry", John Wiley \& Sons, p. 297 (1980).

[3] P. J. Durrant and B. Durrant, "Introduction to Advanced Inorganic Chemistry", Longman, p. 533 (1970).

[4] R. E. Mesmer, C. F. Baes, J. R and F. H. Sweeton, "Acidity Measurements at Elevated Temperatures", VI. Boric acid Equilibria, Inorganic Chemistry, 11(3), pp. 537-543 (1972).

[5] Y. Magara, A. Tabata, M. Kohki, M. Kawasaki and M. Hirose, "Development of boron reduction system for sea water desalination", Desalination, 118, pp. 25-34 (1998).

[6] T.Y. Cath, A.E. Childress and M. Elimelech, "Forward osmosis: principles applications, and recent developments", Journal of Membrane Science, 281, pp. 70-87 (2006).

[7] S. Zhao and L. Zou, "Relating solution physicochemical properties to internal concentration polarization in forward osmosis", Journal of Membrane Science, 379, pp. 459-467 (2011).

[8] M. Wilf, "The guidebook to membrane desalination technology", Balaban Desalination, p. 197 (2007).

[9] Y. Cengeloglu, G. Arslan, A. Tor, I. Kocak and N. Dursun, "Removal of Boron from Water by Using Reverse Osmosis", Separation and Purification Technology, 64, pp. 141-146 (2008). 